\title{
Development policy in the Mazovia region 1998-2018
}

\section{Adam Struzik}

\begin{abstract}
The article presents an overview of the Mazovian regional government's development policy during the two decades since the changes in the administrative division of Poland. The legislative context is presented, with particular focus on the acts which determined the role of regional governments in the implementation of development policy. Next, the horizontal and historical consistency of Mazovia's development policy is presented and set against the problems resulting from faulty redistribution mechanisms (the so-called "Robin-Hood tax"). Some changes serving to fix the mechanism are identified. The distribution of European funds is mentioned in the context of modifications to the statistical division of Mazovia (effective as of 2018), as the new NUTS-2 regions have a direct impact on the structural funds available to Mazovia. The article also presents Mazovia's cooperation with foreign regions and international institutions outside the EU. Finally, the effects of the implementation of Mazovia's development policy in 1998-2018 are discussed.

The article is based on an earlier, Polish-language version, published in issue 25 of Mazovia: Regional Studies. The data and information analyzed in the article were collected in the Mazovian Office for Regional Planning. The presentation of a 20-year overview of the Mazovian regional government's activity in one article allows for a new perspective on the effects and added value of the implementation of a consistent development policy in the region.
\end{abstract}

Key words: regional development, regional government, development policy, Mazovia

\section{The reform of Poland's administrative division and new legal regulations}

The reform of the administrative division of Poland was prepared and passed in 1998 and implemented in 1999. It empowered Polish regions, thus enhancing the effectiveness of regional policy. 49 regions were replaced by 16 . The reform delegated part of the executive and planning powers to regional governments. The Act on regional government ${ }^{1}$ specified the duties and powers of regional governments. The regional council became the legislative and controlling organ while the regional government became the executive organ. The rationale for the administrative division included the need to constitute such regions as would be able to economically and culturally cooperate as partners with other territorial units in European Union countries, as well as with EU organs (so that they would be able to make use of the instruments of EU regional policy). ${ }^{2}$

\footnotetext{
1 Ustawa z dnia 5 czerwca 1998 r. o samorządzie województwa, Dz.U. z 2017 r., poz. 2096, Dz.U. z 2018 r., poz. 130.

2 Ocena nowego zasadniczego podziału terytorialnego państwa przyjęta przez Radę Ministrów w dniu 12 grudnia 2000 r., przygotowana przez Ministerstwo Spraw Wewnętrznych i Administracji, Warszawa, Druk nr 538 z 14 grudnia 2000 r., Senat Rzeczypospolitej Polskiej.
} 
Since the reform, a regional government implements a development policy based on a strategy which includes such elements as ensuring sustainable development, improving the competitiveness and innovativeness of the economy, sustaining the state of the natural environment and shaping and sustaining spatial order in the region. An important instrument in the implementation of the regional government's development policy is the regional spatial development plan.

The Regional Government of Mazovia has, since the reform of the administrative division, paid attention to adopting a strategic, integrated approach to development policy, a policy oriented towards creating an innovative, competitive and territorially cohesive region. In 1999 the regional government established the Mazovian Office for Spatial Planning and Regional Development. This specialized institution was one of the first in Poland to apply an integrated approach to spatial planning and regional programming, treating them as a single process. The office functions to this day, except that its name has been shortened to the Mazovian Office for Regional Planning. Efforts on the part of the office resulted in the first Regional Development Strategy of Mazovia being adopted as early as January 2001, and the Spatial Development Plan of Mazovia - three years later.

The regional government has only limited influence on the region's spatial development - the regional spatial development plan was never a normative act. The new Act on spatial planning and management of $2003^{3}$ did not change this, even though it upheld the regional government's responsibility for formulating and implementing spatial policy. In effect, the regional government can only influence spatial management when it checks local spatial development acts for consistency with the regional spatial development plan and regional government tasks.

The last legal act to determine the scope of the regional government's activities was the Act on the principles of implementation of development policy, passed in $2006{ }^{4}$ The act made the regional government responsible for making effective use of European funds designated for regional development. In effect, documents prepared by the regional government - regional operational programs (for the periods of 2007-2013 and 2014-2020) enabled the completion of many important projects, including infrastructural ones.

\section{Mazovia's integrated development policy}

Mazovia's development strategy and spatial development plan are elements of the region's integrated development policy which takes into account economic, social and spatial aspects. The integration is visible in the consistency of the themes and development goals identified in the current Development Strategy of the Mazowieckie Voivodship 2030: Mazovia as an Innovative Region (SRWM 2030) of October 2013 with the spatial policies specified in the current Spatial Development Plan for the Mazowieckie Voivoideship (PZPWM) adopted

\footnotetext{
Ustawa z dnia 27 marca 2003 r. o planowaniu i zagospodarowaniu przestrzennym, Dz.U. z 2017 r., poz. 1073, 1566.

4 Ustawa z dnia 6 grudnia 2006 r. o zasadach prowadzenia polityki rozwoju, Dz.U. z 2017 r., poz. 1376.
} 
in July 2014. Both documents not only consistently indicate the directions of the region's development, but also the spatial areas where support should be concentrated. In SRWM 2030 these are areas of strategic intervention and in PZPWM - problem areas and functional areas (cf. Table 1).

Mazovia's development policy has from the start been characterized by consistency of strategic and planning documents, but also by consistency across time. This is visible in the continuity of goals in subsequent versions of the main regional strategic document, i.e. the region's development strategy.

Table 1. Consistency of development policy in key Mazovian strategic and spatial planning documents

\begin{tabular}{|c|c|}
\hline $\begin{array}{l}\text { Development Strategy of the Mazowieckie } \\
\text { Voivodship 2030: Mazovia as an Innovative Region - } \\
\text { themes and development goals }\end{array}$ & $\begin{array}{l}\text { Spatial Development Plan for the Mazowieckie } \\
\text { Voivoideship - spatial policies }\end{array}$ \\
\hline $\begin{array}{l}\text { Industry and production } \\
\text { Development of export-oriented production in the } \\
\text { fields of medium and high-tech technology and the } \\
\text { agri-food sector }\end{array}$ & $\begin{array}{l}\text { Industrial development } \\
\text { Development and modernization of rural areas }\end{array}$ \\
\hline $\begin{array}{l}\text { The economy } \\
\text { Increasing the regions' competitiveness via } \\
\text { development of economic activity and transfer and } \\
\text { implementation of new technologies }\end{array}$ & $\begin{array}{l}\text { Improvement of the functional and spatial } \\
\text { structure of the region } \\
\text { Enhancement of the competitiveness of chosen } \\
\text { settlements } \\
\text { Development and modernization of rural areas }\end{array}$ \\
\hline $\begin{array}{l}\text { Space and transportation } \\
\text { Improving accessibility and territorial cohesion, } \\
\text { implementing orderly spatial development }\end{array}$ & $\begin{array}{l}\text { Improvement of transport accessibility and } \\
\text { efficiency (the transport network - road, rail, } \\
\text { bicycle) }\end{array}$ \\
\hline $\begin{array}{l}\text { Society } \\
\text { Improving the quality of life and making better use of } \\
\text { human and social capital in order to build a modern } \\
\text { economy }\end{array}$ & Increase of public safety \\
\hline $\begin{array}{l}\text { Environment and energy } \\
\text { Ensuring a diversified supply of energy and sustainable } \\
\text { use of natural resources }\end{array}$ & $\begin{array}{l}\text { Development of technical infrastructure systems } \\
\text { Increase of resilience to natural hazards } \\
\text { Development and protection of natural resources } \\
\text { and values and improvement of environmental } \\
\text { standards }\end{array}$ \\
\hline $\begin{array}{l}\text { Culture and heritage } \\
\text { Making use of cultural potential, cultural heritage } \\
\text { and environmental assets to enhance economic } \\
\text { development and improve the quality of life }\end{array}$ & $\begin{array}{l}\text { Improvement of transport accessibility and } \\
\text { efficiency (the transport network - bicycle) } \\
\text { Guardianship and protection of cultural heritage } \\
\text { and goods of modern culture } \\
\text { Increase of touristic attractiveness }\end{array}$ \\
\hline Areas of strategic intervention (OSI) & $\begin{array}{l}\text { Enhancement of the competitiveness of chosen } \\
\text { settlements } \\
\text { Problematic areas, functional areas }\end{array}$ \\
\hline
\end{tabular}




\section{Mazovia's development and the regional subvention}

One of the important barriers which hampered the implementation of Mazovia's development policy was the Polish regional subvention system, also known as "the Robin Hood tax". The Act on the income of local and regional government units of $2003^{5}$ introduced a mechanism which transfers part of the income of regions with higher tax incomes to those with lower ones (via the central budget). The algorithm used to calculate the amount to be transferred effectively resulted in all of a well-developing region's income growth above a certain level having to be paid to the national budget.

What was not taken into account was the current economic situation - local and regional governments' incomes were calculated according to data from two years earlier. In effect, the Robin Hood tax became especially problematic during the economic crisis which was preceded by years of rapid economic growth. The gravity of the problem was visible in the effective income of the Mazovia region per inhabitant. For example, in 2011, taking into account the difference in time between the contribution to and benefits from the regional subvention, the level of effective income was below 400 PLN, one of the lowest in Poland. Such a situation forced Mazovia, a rapidly developing region with one of the lowest costs of government (administration) per inhabitant, to take out loans for current expenditure.

The loss of income due to the regional subvention significantly hampered the implementation of development policy, especially infrastructural investments. At risk were not only investments to be financed with Mazovia's own funds, but also those subsidized as part of cohesion policy, as the region lacked funds for the required own contribution. The subvention system mechanism of reducing interregional disparities required repair.

The efforts of the Regional Government of Mazovia, with the substantive support of the Mazovian Office for Regional Planning, resulted in the system being modified. In March 2014, the Constitutional Tribunal announced a key verdict which confirmed that the regional subsidy regulations are incompatible with the Constitution of Poland as they do not guarantee that the region will have sufficient funds to cover the costs of fulfilling its own tasks. The verdict entailed changes to the system of collecting contributions to the regional subvention system which at least partly solved the problems in the Act on the income of local and regional government units. An important fault of these modifications is that they are temporary. Subsequent temporary solutions were prolonged, so far up to 2019. It is to be expected that a definitive change will eventually be introduced. All the more so, taking into account the functions which Warsaw fulfills as the capital of Poland and the largest agglomeration in Poland, functions which require higher expenditure on infrastructure (the subway, ring roads, better energy security), protection of the natural environment and improving air quality.

5 Ustawa z dnia 13 listopada 2003 r. o dochodach jednostek samorządu terytorialnego, Dz.U. z 2017 r., poz. 1453. 


\section{Mazovia's partition into territorial units for statistics (NUTS)}

In 2000 Poland introduced a partition of the country into territorial units for statistical purposes (NUTS) in accordance with the rules of Eurostat. All 16 Polish regions, including Mazovia, were classified as NUTS-2 regions. However, Mazovia's dynamic development and internal differences quickly resulted in a situation in which the average regional indicators did not accurately reflect the situation of the parts of the region outside the metropolitan area.

Data from the European Statistical Office indicates that in 2008-2014, Mazovia achieved one of the highest rates of growth of GDP per capita (measured at purchasing power parity) among European regions. With a growth rate of nearly 25 percentage points, from $85 \%$ of the EU average to $108 \%$, Mazovia surpassed 275 other regions and was among the first three fastest developing regions in the European Union.

Classifying all of Mazovia, according to average data for the region, as a more developed region would result in a significant limitation of funds for investments in infrastructure. Taking this into account, the Regional Government of Mazovia started to lobby for a new statistical partition, one taking into account the internal differences of the region, at the beginning of the 2007-2013 financial perspective. As the change did not come into force before the 2014-2020 perspective, in the Partnership Agreement of 2014 The Government of the Republic of Poland decided [...] to minimalize the negative effects of [Mazovia's] classification as a better developed region by increasing its allocation [of structural funds] by a full $3 \%{ }^{6}$

In 2015 a team consisting of representatives of the regional and national governments prepared the "premises for a modification of the statistical partition" which were adopted by the national government and, after that, by the European Commission. In effect, since January 2018, Mazovia is formally a NUTS-1 macro-region consisting of two NUTS-2 regions: the Warsaw capital region which includes Warsaw and 9 surrounding counties, and the Mazovian regional region which includes the remaining part of Mazovia. The statistical division will allow for an allocation of European funds better suited to the individual parts of Mazovia, both in terms of quantity and type of aid. The new NUTS-2 units provide a much more objective illustration of the social and economic situation of Mazovia, reflecting the significant differences in levels of GDP between subregions. The area around the capital has a GDP per capita much above the EU average while the Mazovian regional region does not cross the $75 \%$ threshold. The new statistical partition will allow for more adequate intervention in both areas after 2020. A higher level of funding will be available to the problem areas identified in the regional development strategy.

\footnotetext{
6 Programowanie perspektywy finansowej 2014-2020-Umowa Partnerstwa, Ministerstwo Infrastruktury i Rozwoju, 2014.
} 


\section{Mazovia's international contacts and cooperation}

As was mentioned at the beginning of the article, one of the goals of the change of Poland's administrative division was enabling effective international cooperation on the level of regions. Mazovia has a Brussels office since 2002 and, since 2006, is implementing a consistent policy of international cooperation in accordance with the priorities adopted by the Regional Council. Interregional partnerships and contacts have been made and are sustained with European regions as well as Asian ones (in China, Korea, India). This allows for better economic cooperation, exchange of experience and information, and ensures conditions for effective cooperation between companies and organizations. Mazovia has signed 20 cooperation agreements, plus letters of intent with the Brazilian state of Santa Catarina, the Korean North Gyeongsang Province and the Indian state of Gujarat. Cooperation also takes place within the "Little Weimar Triangle", in accordance with a joint declaration by Mazovia, Brandenburg and Île-de-France.

Apart from bi- and trilateral cooperation, Mazovia consistently takes an active part in the proceedings of international organizations and institutions grouping local and regional governments from European countries. Mazovia has its representatives in the forums of, for example, the Airport Region Conference (ARC), Peri-Urban Regions Platform Europe (PURPLE), the Network of European Regions Using Space Technologies (NEREUS), the European Chemical Regions Network (ECRN), the Environmental Conference of the Regions of Europe (ENCORE), the European Social Network (ESN), the Network of European Metropolitan Regions and Areas (METREX) and the Visegrad Group Forum of Regions.

\section{Investments in Mazovia}

After the reform of Poland's administrative division, regions were granted the power and responsibility of implementing their own development policies. The relevant changes included shifting various rights and duties to the regional level and ensuring financial independence for carrying out key regional projects. The Mazovian regional government's policy was based on the development strategies discussed earlier. Both these documents and the regional programs based upon them were the bases for the implementation of development policy in the region, decisions concerning the current activity of the regional government, negotiating regional and territorial contracts and applying for external funds, including European ones. Since the constitution of the region, the Mazovian government was focused on carrying out projects serving to increase the region's competitiveness and cohesion. An important role was played by regional programs: The Regional Development Program of Mazovia 2001-2006, The Regional Operational Program of Mazovia 2007-2013 and the current Regional Operational Development Program of Mazovia 2014-2020. 
In 1999-2002 important multiannual development projects were carried out with co-financing from the national budget. They concerned mostly road infrastructure and healthcare. Grants of 834 million PLN accounted for c. $16 \%$ of national grants. ${ }^{7}$

Before accession to the European Union, the main Polish medium-term development strategic document was the Preliminary National Development Plan 2000-2003 (WNPR). The plan was realized through national and regional programs. It was implemented partly through the funds available as part of the Union's aid programs before Poland's accession to the EU: PHARE - a program supporting economic and social change in candidate countries, ISPA - financial support from EU funds for significant national projects concerning the development of infrastructure, protection of the environment and transport, and SAPARD - a program for the development of agriculture and rural areas. The WNPR was the basis for the signing of financial memoranda with the European Commission which allowed for projects to be implemented as part of operational projects at the regional level.

PHARE 2000, 2001 and 2002 included grants for 370 projects in Mazovia for a total sum of 6.1 million EUR. The total value of all the projects which were qualified for grants from the program equaled 23.4 million EUR and EU funds accounted for $26 \%$ of the qualified costs. ${ }^{8}$

Funds from ISPA/the Cohesion Fund were used in Mazovia to implement 6 large projects concerning protection of the natural environment. Their total value was 341 million EUR, of which 211 million EUR was provided from EU funds. The projects concerned improvement of water quality, waste management and land protection. Transport-related projects in Mazovia totaled to 801 million EUR, of which 578 million was provided from EU funds. ${ }^{9}$

Regional contracts played an important role in preparing Poland for the absorption of structural funds and external aid. In 2001-2004 the projects realized as part of the I (20012003) and II (2004) Contracts were worth 1.9 billion PLN of which 52\% was provided by the national budget and $48 \%$ by local and regional governments. The projects realized included $4 \mathrm{~km}$ of the first subway line and the Northern Waterworks in Warsaw, investments in over $130 \mathrm{~km}$ of local roads, 350 educational institutions and 13 health- and social care institutions. The 2005-2006 Regional Contract for Mazovia focused on health- and social care, with a total value of 45 million PLN.

In 2004-2006 the key program was the Integrated Regional Development Operational Program (ZPORR) which was implemented on the national level. The Program served to implement the National Development Plan/Community Support Framework 2004-2006. Mazovia received c. 300 million EUR which were invested in the development of public transport in the Warsaw agglomeration, upgrading of roads, municipal infrastructure, but also healthcare, education, ecology, science, culture, art and tourism.

\footnotetext{
7 A. Młynarska-Witkowska, Informacja o dotacjach z budżetu państwa do inwestycji wieloletnich w latach 1999-2001 oraz planowanych na 2002 r. w układzie wojewódzkim. Informacja nr 837 (IP-97G), Biuro Studiów i Ekspertyz Kancelarii Sejmu.

8 Wykorzystanie środków wsparcia w projektach rozwoju województwa mazowieckiego w latach 1999-2004, Mazowieckie Biuro Planowania Przestrzennego i Rozwoju Regionalnego, Warszawa 2005, pp. 62-63, unpublished work.

9 Ibidem, pp. 12-13, 27-28.
} 
Implementation of the Regional Operational Program of Mazovia 2007-2013 (RPO WM 2007$2013)^{10}$ resulted in 2412 contracts being signed for projects worth 3.1 billion EUR. Funding from the European Fund for Regional Development (EFRD) accounted for c. 1.7 billion EUR. The Indicative List of Key Projects (IWPK) ${ }^{11}$ included 126 projects worth nearly 6 billion EUR, including 3.7 billion from the EFRD.

The RPO WM 2007-2013 had seven main priority axes. Priority 1 "Creating conditions for development of innovation potential and entrepreneurship in Mazovia" was oriented towards supporting the research and development sector, strengthening ties between scientific institutions and enterprises, preparing areas for economic activity, strengthening business environment institutions, encouraging entrepreneurship and strengthening cooperation at the regional level. 1220 projects were realized, including 36 from the IPWK.

Priority 2 "Accelerating the e-development of Mazovia" focused on activities supporting the development of the information society. 263 projects were realized, including 8 from the IPWK. As a result, 397 institutions and 2 million people acquired access to the internet and 2011 on-line services were launched.

Projects realized as part of priority 3 "The regional transport system" were to improve the spatial cohesion of Mazovia and support the diffusion of development processes from the development core (Warsaw) and from subregional cities to the remainder of the region. The projects focused on improving the quality of the regional road network, road safety, accessibility and service quality of public transport in the region and developing a regional airport. 288 projects were realized, including 8 from the IWPK.

Priority 4 "The environment, prevention of threats, and energy" allowed for the implementation of projects oriented towards the improvement of the state of the natural environment, particularly through building or upgrading infrastructure serving to limit pollution and its negative effects. Other projects included electricity infrastructure and district heating installations, renewable energy sources and prevention of natural disasters. 194 projects were realized, including 14 key projects. As a result, the length of the water supply network increased by $669 \mathrm{~km}$ and that of the sewage network by $946 \mathrm{~km}$ which resulted in, respectably, 31 and 44 thousand people gaining access to the networks. Over 52 thousand hectares of land inhabited by over 150 thousand people gained flood protection. The fact that the projects served to limit social and economic disproportions is visible in that half of the projects (97 out of 194, 47\% in terms of value of co-financing) were realized in areas identified in the Development Strategy of the Mazowieckie Voivodship 2020 as problem areas, including the Ostrołeka (26 projects), Bug River (24) and Radom (22) areas.

\footnotetext{
${ }^{10}$ Data concerning RPO WM 2007-2013 was taken from the report: Sprawozdanie końcowe z realizacji Regionalnego Programu Operacyjnego Województwa Mazowieckiego 2007-2013.

${ }^{11}$ Projects considered to be of strategic importance and realized without the need to participate in a competition for funds. More information available [in:] Indywidualne projekty kluczowe RPO WM 2007-2013 a realizacja celów SRWM, Mazowsze. Analizy i Studia, 5, 36, 2015, Warszawa.
} 
Priority 5 "Strengthening the role of cities in the development of the region" included projects oriented towards making use of cities' endogenic potentials in order to activate the region in socio-economic terms, ones focused on public transport and urban renewal. 10 public transport projects were carried out and 28 urban renewal ones, encompassing 20 hectares.

Projects in priority 6 "Making use of nature and culture for the development of tourism and recreation" can be divided into two categories: culture and tourism. In the former, 124 projects were carried out, including 21 key projects serving to improve cultural services and accessibility to culture and 7 key projects concerning the promotion of the region and making it more attractive for tourists. Projects also concerned the building or modernization of 151 cultural institutions' buildings and objects. In the category of tourism, touristic infrastructure was developed. 219 projects, including 7 from the IWPK, resulted in the creation of $1145 \mathrm{~km}$ of tourist trails, $669 \mathrm{~km}$ of bicycle paths, 71 tourist information portals and 565 new tourist products.

Priority 7 "Creating and improving conditions for human capital development" allowed for important projects to be realized, improving the state and accessibility of healthcare and educational infrastructure. In healthcare, 52 projects were realized, including 17 key ones serving to improve the state of medical infrastructure and providing medical equipment which enabled 864 thousand specialized diagnoses a year. In the category of education, projects served to ensure good teaching conditions which contributed to increasing the region's competitiveness and developing human capital. 89 projects were realized, including 4 from the IPWK. Funds were granted to a total of 306 educational institutions teaching 98 thousand students. Another category of projects in priority 7 was social care infrastructure: 26 such objects were built, modernized or equipped, resulting in the creation or sustaining of the capability to take care of 985 people therein.

The number of investments in regional roads in Mazovia is constantly growing. In 1999_ 2017505 such projects were realized. They were oriented towards increasing the capacity of important transport corridors. In several cases, entire roads were the subject of modernization (i.e. roads number $617,637,732$ ). In time, the approach to modernization became more comprehensive, as can be seen on roads no. 801, 728, 727, 694, which were modernized in subsequent programming periods (Fig. 1).

In the 2014-2020 programming period, development projects in Mazovia are implemented primarily through the Regional Operational Program of Mazovia 2014-2020 (RPO WM 20142020). The total value of European funds available through this program is over 2 billion EUR of which $3 / 4$ are funds from the European Regional Development Program and $1 / 4$ comes from the European Social Fund. Taking into account that the maximum rate of co-financing is $80 \%$, the funds will enable the realization of projects worth over 2.5 billion EUR.

Part of the funds is dedicated to projects realized through Integrated Territorial Investments (ITI) in the Warsaw Functional Area. One such project is the creation of a Virtual Warsaw Functional Area consisting of mobile facilities in five areas: e-accessibility, e-tourism, e-public transport, e-parking and e-environment. The total cost of the project is 70 million PLN (c. 16.5 million EUR) of which $80 \%$ is covered by EU funds. 


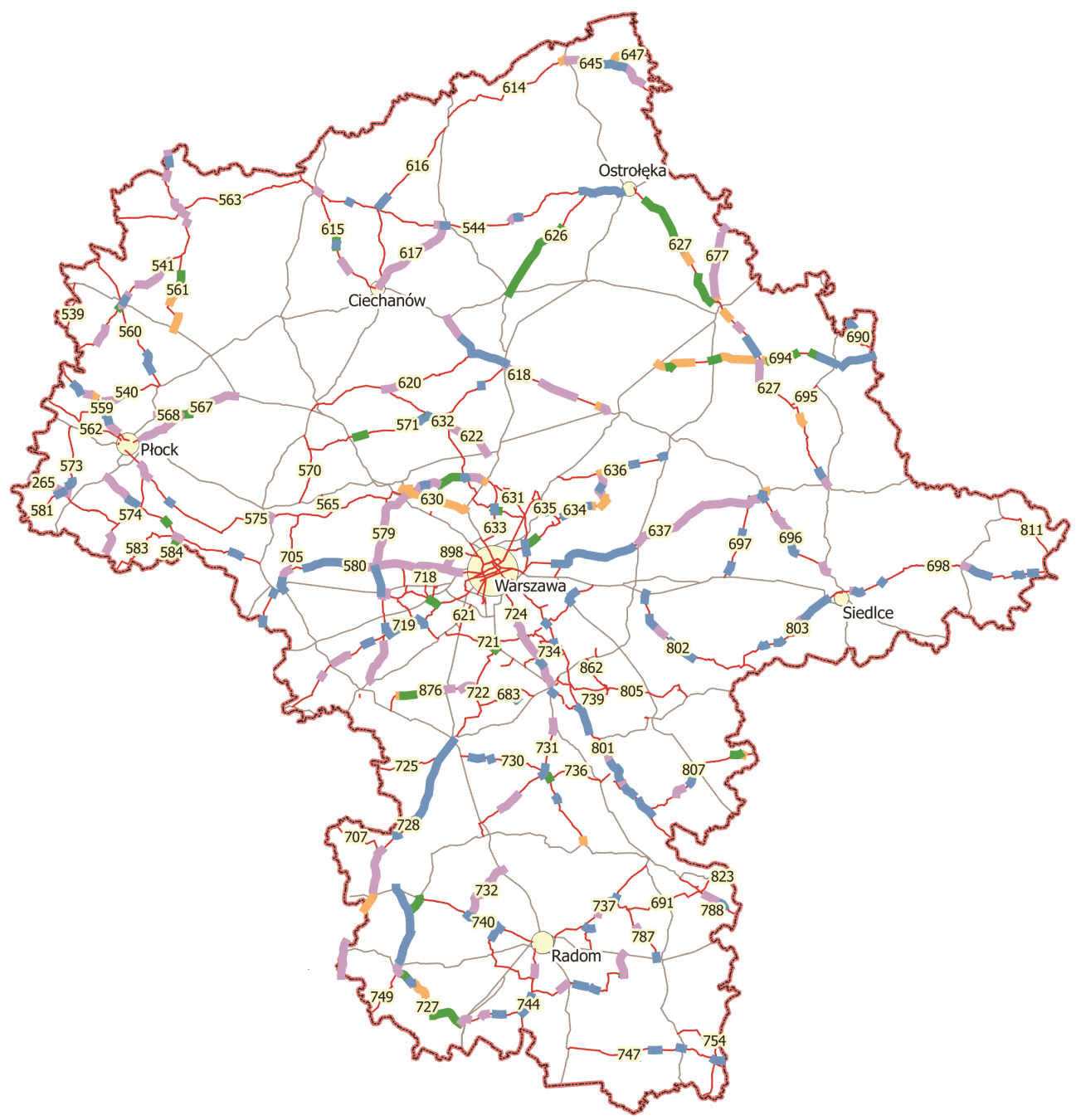

Investments by the Mazovian Regional Road Authority (MZDW) in the years:

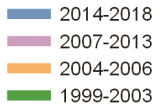

Main cities:

capital
regional centers
- subregional centers
Other:

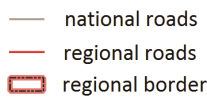

Figure 1. Regional road investments

Source: own work by the Mazovian Office for Regional Planning in Warsaw 
The Regional Government of Mazovia initiated a mechanism parallel to ITI within RPO WM 2014-2020. Regional and subregional cities and their functional areas gained access to Regional Territorial Investments (RIT). The RIT mechanism enables and encourages cooperation between local (municipal and county) governments and coordination of projects so that a higher value added can be achieved.

As the current regional operational program is being implemented, by the beginning of June 2018 over 2100 contracts were signed for the co-financing of projects with nearly 5 billion PLN (c. 1.17 billion EUR). This means that the majority of available funds has already been contracted. The key projects in this perspective include the upgrading of 39 electric multiple unit trains by the regional train operator, Koleje Mazowieckie (198 million PLN, including 128 million from the RPO WM 2014-2020) and investments in healthcare, including the building of a new psychiatric hospital in Ząbki, the most modern one in Poland, next to an older establishment in Drewnica (137 million PLN, including 96 million from the RPO WM).

A number of R\&D projects are also being carried out, among them: Creating a Center for Intelligent Specializations in Innovative Industrial Technology and Technical and Environmental Safety; the ITeE-PIB Prototype Center; the Center for Food and Nutrition - modernizing the SGGW (Warsaw University of Life Sciences) campus in order to create a Research \& Development Center for Food and Nutrition; the Mazovian Mother and Child Research \& Development Diagnostics Center; the Center for Preclinical Analyses and Technologies - CePT II; Creating a Central Mechanics and Construction Laboratory in Płock.

Another project, implemented by Bank Gospodarstwa Krajowego is called „Financial instruments for Mazovian SMEs". It serves to support small and medium enterprises from Mazovia in investing in increasing their competitiveness and innovativeness.

Mazovia has also signed a Territorial Contract with the national government. The document lists projects important to the development of the country and region. However, their placement on the contract's list does not guarantee that they will be realized - this depends on the availability of funds in national programs and the RPO WM 2014-2020.

\section{Conclusion}

Development policy in Mazovia in 1998-2018 was implemented by the regional authorities according to the region's key documents: the development strategy and spatial development plan of Mazovia, and the current development programs, including the regional operational program. The projects realized during these two decades in Mazovia contributed to the region's growing competitiveness and accessibility, helped protect the environment and improve the quality of life in all of Mazovia as support was addressed both to cities and rural areas.

The Mazovian regional government's experience in implementing development policy confirms that the reforms which gave greater independence to Polish regions allowed them to achieve important public goals through enabling them to acquire their own funds and giving access to European funds. The Mazovian regional government's activity contributed 
to a significant increase in the amount of European funds available to the region in the 2014-2020 programming perspective. The solutions prepared by the region concerning its statistical partition, in particular the demarcation of a new NUTS-2 Warsaw metropolitan area, will undoubtedly positively influence the amount and type of funds available to the remaining, non-metropolitan part of the region after 2020. A problem which still needs to be solved permanently is the faulty system of regional subvention - hence continuous efforts are being undertaken in order to work out a solution better suited to the needs of Mazovia.

\section{Realizacja polityki rozwoju województwa mazowieckiego w latach 1998-2018}

\section{STRESZCZENIE}

Celem artykułu jest przegląd polityki rozwoju województwa mazowieckiego na przestrzeni ostatnich dwudziestu lat. W artykule omówiono reformę podziału administracyjnego Polski wprowadzoną na przełomie 1998 i 1999 roku oraz zmiany legislacyjne determinujące zakres kompetencji samorządu województwa w zakresie prowadzenia polityki rozwoju. Następnie przedstawiono zintegrowaną politykę rozwoju realizowaną w województwie mazowieckim w ujęciu horyzontalnym (integracja dokumentów strategicznych i planistycznych) oraz historycznym (konsekwencja w ustalaniu i realizacji celów rozwoju). Praktyka wdrażania polityki rozwoju została zestawiona z problemami wynikającymi z subwencji regionalnej (tzw. ,janosikowego"). Wskazano przy tym na postępy w zakresie naprawy wadliwego mechanizmu redystrybucji środków między województwami. Kwestia dystrybucji środków z poziomu unijnego została wspomniana przy omawianiu zmian w podziale statystycznym województwa (na jednostki NUTS -2), jako że jest to czynnik mający bezpośredni wpływ na wysokość i rodzaj wsparcia w ramach polityki spójności. Poza działalnością na poziomie Unii Europejskiej, omówiono współpracę województwa mazowieckiego z innymi regionami i instytucjami na poziomie międzynarodowym. W ostatniej części artykułu przedstawiono efekty realizacji polityki rozwoju województwa mazowieckiego w latach 1998-2018. Działania realizowane w poszczególnych okresach zilustrowano przykładami najważniejszych inwestycji i projektów oraz zestawiono z aktualnymi dokumentami wdrożeniowymi.

Artykuł został przygotowany na podstawie analizy danych i informacji zebranych w Mazowieckim Biurze Planowania Regionalnego w Warszawie. Zestawienie w jednym miejscu informacji na temat dwudziestu lat funkcjonowania Samorządu Województwa Mazowieckiego pozwoliło na przedstawienie, z nowej perspektywy, efektów i wartości dodanej prowadzenia konsekwentnej polityki rozwoju w regionie.

Słowa kluczowe: rozwój regionalny, samorząd terytorialny, polityka rozwoju, województwo mazowieckie 